\title{
PERJANJIAN BAKU MENURUT PRINSIP SYARIAH (Tinjauan Yuridis Praktik Pembiayaan di Perbankan Syariah)
}

\author{
Dwi Fidhayanti \\ Fakultas Syariah UIN Maulana Malik Ibrahim Malang \\ fidha.shi@gmail.com
}

\begin{abstract}
Nowadays many economic transactions conducted through the bank. In Indonesia, the banks can be divided into two, namely conventional banks and Islamic banks. The development of financing in Islamic banks illustrates that this product enjoyed by many people. To that end, the Islamic banking is necessary to a healthy financial services and in accordance with Islamic principles. This paper aims to assess How raw agreement according to Islamic principles and what the legal consequences of raw agreement on financing in Islamic banking for the parties. This paper uses the type of normative research to conduct legal interpretation of the material to obtain a solution to the problem. Results and discussion shows that raw raw agreement has been made legally, but do not pay attention to one of the Islamic principles set out in the acceptance of products and product distribution of funds in Islamic banking, the balance (tawâzun). Standard contract after an analysis according to Islamic principles, including the damaged or imperfect agreement because the agreement has been made legally, but there is one principle which is not fulfilled then make the agreement unenforceable. imperfect agreement did not result in legal consequences for the parties.

Transaksi ekonomi dewasa ini banyak dilakukan melalui bank. Di Indonesia, bank dibedakan menjadi dua, yaitu bank konvensional dan bank syariah. Berkembangnya pembiayaan di bank syariah menggambarkan bahwa produk ini dinikmati oleh banyak kalangan. Untuk itu, dalam perbankan syariah diperlukan adanya jasa keuangan yang sehat dan sesuai dengan prinsip syariah. Tulisan ini bertujuan untuk mengkaji Bagaimana perjanjian baku menurut prinsip syariah dan Apa akibat hukum dari perjanjian baku pada pembiayaan di perbankan syariah bagi para pihak. Tulisan ini menggunakan jenis penelitian normatif dengan melakukan intepretasi terhadap bahan hukum sehingga didapatkan solusi atas permasalahan. Hasil dan pembahasan menunjukkan bahwa perjanjian baku baku telah dibuat secara sah, namun tidak memperhatikan salah satu prinsip syariah yang ditetapkan pada produk penerimaan dan produk penyaluran dana pada perbankan syariah, yaitu keseimbangan (tawâzun). Perjanjian baku setelah dilakukan analisis menurut prinsip syariah termasuk pada perjanjian yang rusak atau fasid karena perjanjian tersebut telah dibuat secara sah, namun terdapat satu prinsip yang tidak dipenuhi yang kemudian membuat perjanjian tersebut tidak dapat diterapkan. perjanjian yang fasid tidak menimbulkan akibat hukum bagi para pihak.
\end{abstract}

Kata kunci: Perjanjian baku, prinsip syariah

Manusia sebagai makhluk sosial selalu berinteraksi dengan sesamanya. Manusia tidak dapat memenuhi kebutuhannya hidup dengan dirinya sendiri. Manusia yang satu dengan yang lainnya saling ketergantungan dan membutuhkan dalam memenuhi kebutuhan hidupnya. Interaksi yang dilakukan bertujuan untuk memenuhi kebutuhan jasmani dan rohani. Tidak hanya itu, sekarang ini interakasi 
yang seringkali dilakukan dan secara terus menerus adalah transaksi ekonomi.

Transaksi ekonomi dewasa ini biasanya dilakukan melalui Bank. Bank memiliki peranan yang cukup penting bagi kehidupan masyarakat dewasa ini. Bank menjadi sarana dalam bertransaksi terutama transaksi yang mempunyai nilai tinggi. Oleh karena itu, kehadiran bank dirasakan penting keberadaanya bagi pelaku bisnis dan masyarakat pada umumnya. Pembayaran dalam transaksi bisnis dengan menggunakan lembaga perbankan dianggap cukup aman dibandingan dengan pembayaran yang dilakukan secara langsung.

Dalam perkembangan perbankan di Indonesia, bank dibedakan menjadi dua, yaitu perbankan konvensional dan perbankan syariah. Menurut pasal 1 ayat (1) undangundang No. 21 Tahun 2008 tentang perbankan syariah, Perbankan Syariah adalah segala sesuatu yang menyangkut tentang Bank Syariah dan Unit Usaha Syariah, mencakup kelembagaan, kegiatan usaha, serta cara dan proses dalam melaksanakan kegiatan usahanya. Karena perbankan syariah termasuk baru dalam pengoperasiannya, maka diperlukan pemahaman mengenai perbankan syariah perlu ditingkatkan untuk lebih memahami dan mendapatkan informasi yang lengkap mengenai produk pembiayaan berdasarkan akad-akad syariah sehingga masyarakat dapat menyadari manfaat dan keunggulannya dari perbankan syariah dibandingkan dengan sistem perbankan konvensional yang telah ada dan biasa digunakan sebelum adanya perbankan syariah. $^{2}$

Perbankan syariah pada dasarnya melakukan kegiatan yang sama dengan perbankan konvensional, yaitu menghimpun dana dan menyalurkan dana masyarakat selain dari pada juga menyediakan jasa keuangan lainnya. Dalam hal menghimpun dana dari masyarakat perbankan syariah melakukan mobilisasi dan investasi tabungan dengan cara yang adil. Mobilisasi dana dalam Islam sangat diajurkan karena menumpuk dan menimbun harta tidak

\footnotetext{
${ }^{1}$ Hermansyah, Hukum Perbankan Nasional Indonesia, (Jakarta: Kencana, 2005), h. 68.

${ }^{2}$ Muhammad Djumhana, Hukum Perbanakan di Indonesia, (Bandung: Citra Aditya Bakti, 1996), h. 148149.
}

diperkenankan. Untuk itu dana tersebut dirasakan perlu digunakan secara produktif. $^{3}$ Karakteristik unik yang terdapat pada perbankan syariah adalah dalam menghimpun dana dari masyarakat tidak menggunakan unsur bunga atau dalam islam disebut riba. Menurut Hukum Islam, Riba termasuk pada hal yang diharamkan. Sementara, dalam hal penyaluran dana, perbankan syariah menyalurkan danadananya melalui pembiayaan-pembiayaan yang dikategorikan menjadi enam kategori berdasarkan tujuan penggunaannya, yaitu: pembiayaan berdasarkan pola jual-beli dengan akad murâbahah, salam dan istishna'; pembiayaan bagi hasil berdasarkan akad mudhârabah atau musyârakah, pembiayaan dengan akad qard, pembiayaan penyewaan barang bergerak atau tidak bergerak kepada nasabah berdasarkan akad ijârah atau sewa beli dalam bentuk ijârah muntahiya bittamlik; pengembalian utang berdasarkan akad hawâlah; dan pembiayaan multijasa. ${ }^{4}$

Pembiayaan-pembiayaan tersebut sangat dinikmati oleh nasabah perbankan syariah serta juga diminati oleh masyarakat Indonesia karena system keuangan syariah menjadi salah satu keuangan yang mampu bertahan dalam krisis ekonomi dan keuangan global yang terjadi. Dengan demikian perbankan syariah semakin berkembang pesat. Perkembangan perbankan syariah merupakan perwujudan dari kebutuhan masyarakat yang menghendaki suatu perbankan yang mampu menyediakan jasa keuangan yang sehat, juga memenuhi prinsip syariah. $^{5}$

Dengan perkembangan perbankan syariah, untuk itu dilakukan inovasi baru dalam mengembangkan usaha. Berbagai inovasi dengan tujuan pengembangan usaha telah melahirkan berbagai bentuk produk. Ini membawa dampak pada pranata hukum sehingga diperlukan pranata hukum yang memadai untuk mengaturnya, demi terciptanya kepastian dan perlindungan hukum bagi para pihak.

\footnotetext{
${ }^{3}$ Andri Soemitra, Bank dan Lembaga Keuangan Syariah, cet, ke-2, (Jakarta: Kencana, 2010), h. 73.

${ }^{4}$ Andri Soemitra, Bank.., h. 78-79.

${ }^{5}$ Burhanuddin Susamto, Aspek Hukum Lembaga Keuangan Syariah, (Yogyakarta: Graha Ilmu, 2010), h. 30.
} 
Untuk menjamin kepastian dan perlindungan hukum pada pembiayaan di perbankan syariah, maka diperlukan adanya suatu perjanjian. Menurut pasal 1313 KUH perdata, perjanjian adalah suatu perbuatan dengan mana satu orang atau lebih mengikatkan dirinya terhadap satu orang lain atau lebih. Dalam menunjang efektivitas operasional dan melindungi kepentingan pihak bank, yang dalam hal ini menjalankan fungsinya sebagai penyalur dana bagi masyarakat, bank syariah menggunakan perjanjian baku dalam menjalankan kegiatannya dalam menyalurkan dana tersebut.

Dalam perjanjian baku dianggap tidak ada keadilan karena perjanjian baku hanya memihak salah satu pihak saja. Draft perjanjian telah disiapkan terlebih dahulu oleh salah satu pihak karena ingin melindungi kemungkinan terjadinya kerugian pada pihaknya. Sementara, pihak lainnya hanya dihadapkan pada pilihan untuk menerima atau menolak perjanjian tersebut atau "take it or leave it contract". 6 Perjanjian ini tidak mengandung unsur kesepakatan karena pihak lainnya, yaitu nasabah mau tidak mau harus menerima setiap klausul yang terdapat pada draft perjanjian. Disini lah letak ketidak adilan dari perjanjian baku.

Karena perjanjian ini digunakan pada pembiayaan syariah, maka dirasakan perlu untuk mengetahui Bagaimana perjanjian baku menurut prinsip syariah dan Apa akibat hukum dari perjanjian baku pada pembiayaan di perbankan syariah bagi para pihak. Dengan adanya pemahaman mengenai perjanjian baku ini, dimaksudkan sebagai tambahan wawasan dan pengetahuan atas perjanjian baku yang sesuai prinsip syariah.

\section{Metode Penelitian}

Jenis penelitian yang digunakan dalam penelitian ini, yaitu penelitian normatif. Penelitian normatif juga dikenal dengan penelitian doctrinal, yaitu penelitian terhadap hukum yang dikonsepsikan dan dikembangkan atas dasar doktrin yang dianut dan

\footnotetext{
6 R. Subekti, Hukum Perjanjian, (Bandung: Intermasa, 1987), h. 19-20.
}

dikembangkan. ${ }^{7}$ Dalam penelitian ini, penulis ingin memecahkan permasalahan berkaitan dengan perjanjian baku apabila dilihat dari segi prinsip syariah. Prinsip syariah dipilih karena masalah ini berfokus pada pembiayaan pada perbankan syariah. Berdasarkan objek penelitannya, pendekatan yang digunakan dalam penelitian ini adalah pendekatan perundang-undangan (statue approach) dan pendekatan konsep (conceptual approach). Jenis dan sumber bahan hukum dalam penelitian normatif meliputi bahan hukum primer, bahan hukum sekunder, dan bahan hukum tersier. ${ }^{8}$

Teknik pengumpulan bahan hukum yang digunakan dalam penelitian ini, yaitu dengan cara mengumpulkan bahan-bahan hukum dengan menggunakan studi kepustakaan. Studi kepustakaan meliputi studi bahan-bahan hukum yang terdiri dari bahan hukum primer, bahan hukum sekunder, dan bahan hukum tersier.

Untuk memecahkan permasalahan penelitian tersebut, peneliti menggunakan intepretasi hukum. Mengintepretasi aturan hukum adalah upaya untuk menemukan makna dari aturan hukum itu, artinya mendistilasi atau menarik keluar dan menampilkannya ke permukaan kaidah hukum atau makna hukum. Dalam penelitian ini difokuskan pada intepretasi gramatikal dan intepretasi ekstensif.

\section{Hasil dan Pembahasan}

\section{Perjanjian Baku Menurut Prinsip Syariah}

Perjanjian secara lebih rinci didefinisikan oleh Subekti yang menyatakan bahwa perjanjian adalah suatu peristiwa dimana seseorang berjanji kepada seseorang yang lain atau dimana dua orang itu saling berjanji untuk melaksanakan suatu hal. ${ }^{9}$ Perjanjian seringkali digunakan dalam transaksi ekonomi di perbankan, termasuk juga perbankan syariah.

Pengaturan perbankan syariah di Indonesia, yaitu pada undang-undang No. 7 tahun 1992 Jo. Undang-undang No. 10 tahun 1998 tentang perubahan undang-undang No. 10 tahun 1992

\footnotetext{
7 Soetandyo Wignyosubroto, Hukum, Paradigma, Metode dan Dinamika Masalahnya, (Jakarta: ELSAM dan HUMA, 2002), hlm. 148.

${ }^{8}$ Soerjono Soekanto dan Sri Mamudji, Penelitian Hukum Normatif: Suatu Tinjauan Singkat, (Jakarta: Raja Grafindo Persada, 2011), hlm. 12-13.

${ }^{9}$ R. Subekti, , Hukum,. h. 1.
} 
tentang perbankan yang didalamnya mengatur secara khusus mengenai bank syariah. Dalam perkembangan terbarunya kemudian pemerintah mengeluarkan undang-undang mengenai perbankan syariah yang dituangkan dalam undang-undang No.21 tahun 2008 tentang perbankan syariah. ${ }^{10}$

Peraturan perbankan syariah mengatur secara spesifik serta lebih memperjelas operasional bank syariah, termasuk didalamnya pengaturan mengenai pembiayaan pada perbankan syariah yang terdapat pada pasal 1 ayat (12) dalam undang-undang No. 21 tahun 2008 tentang perbankan syariah yang menyebutkan bahwa pembiayaan adalah penyediaan dana atau tagihan yang dipersamakan dengan itu berupa: (a) Transaksi bagi hasil dalam bentuk mudhârabah dan musyârokah; (b) Transaksi sewa menyewa dalam bentuk ijarah atau sewa beli dalam bentuk ijârah muntahiya bittamlik; (c) Transaksi jual beli dalam bentuk piutang murâbahah, salam dan istishna; (d) Transaksi pinjam meminjam dalam bentuk piutang qard, dan (e) Transaksi sewa menyewa jasa dalam bentuk ijârah untuk transaksi multijasa.

Kesepakatan para pihak dalam pembiayaan dituangkan dalam bentuk perjanjian atau akad. Pengertian akad dituangkan pada pasal 1 angka (13) undang-undang No. 21 tahun 2008 tentang perbankan syariah yang menyatakan bahwa akad adalah kesepakatan tertulis antara Bank Syariah atau UUS dan pihak lain yang memuat adanya hak dan kewajiban bagi masing-masing pihak sesuai dengan Prinsip Syariah. Dengan adanya pengaturan mengenai penggunaan prinsip syariah sebagai dasar dalam membuat perjanjian, diharapkan undang-undang No. 21 tahun 2008 tentang perbankan syariah dapat memberikan payung hukum sehingga perjajian tersebut tidak bertentangan dengan aturan syariah. Prinsip syariah yang dimaksud kemudian dituangkan pada pasal 1 ayat (12) undang-undang No. 21 tahun 2008 tentang perbankan syariah bahwa prinsip syariah

${ }^{10}$ Dyah Ochtorina Susanti, Mekanisme Pengaturan Hukum Perjanjian Dalam Regulasi perbankan Syariah di Indonesia (Ditunjau dari Sudut Pandang Hukum Islam dan Hukum Perdata (KUHPerdata yang berlaku di Indonesia), Risalah Hukum (Online) Volume 4 No. 2 (http://risalah.fhunmul.ac.id diakses tanggal 12 Februari 2015) h. 93-104. adalah prinsip hukum Islam dalam kegiatan perbankan berdasarkan fatwa yang dikeluarkan oleh lembaga yang memiliki kewenangan dalam penetapan fatwa di bidang syariah.

Fatwa yang berkaitan dengan perbankan syariah dikeluarkan oleh Majelis Ulama Indonesia melalui lembaganya yang bernama Dewan Syariah Nasional. Peran Majelis Ulama Indonesia secara teoritis dengan cara melakukan kajian-kajian atas ekonomi kontemporer dengan menggunakan metodemetode penetapan yang kemudian hasilnya dinyatakan dalam bentuk fatwa. ${ }^{11}$ Tugas dan wewenang Dewan Syariah Nasional diatur dan diakui dalam pasal 26 ayat (1), (2), dan (3) Undang-undang No.21 Tahun 2008 tentang Perbankan Syariah bahwa produk dan jasa perbankan syariah harus sesuai dengan prinsip syariah sebagaimana yang difatwakan oleh Majelis Ulama Indonesia kemudian dituangkan dalam peraturan Bank Indonesia.

Prinsip syariah yang digunakan bekaitan dengan perjanjian yang terdapat pada fatwa diatur secara tersendiri pada tiap produk dan jasa yang terdapat pada perbankan syariah. Saat ini, kebanyakan perjanjian yang terdapat pada perbankan syariah dibuat secara baku dimana beberapa klausula yang terdapat pada perjanjianperjanjian tersebut dapat memberatkan salah satu pihak saja. Memberatkan salah satu pihak maksudnya adalah bahwa dalam perjanjian tersebut hanya menyebutkan hak-hak dari satu pihak saja (yaitu pihak yang mempersiapkan perjanjian baku tersebut) tanpa mencantumkan apa yang menjadi kewajiban pihaknya dan sebaliknya hanya atau terutama menyebutkan kewajibankewajiban pihak lainnya sedangkan apa yang menjadi hak-hak lainnya itu tidak disebutkan. ${ }^{12}$

Bahkan Pitlo menyebutkan perjanjian baku sebagai perjanjian paksaan karena sudah tidak ada lagi kebebasan sehingga pihak yang lemah terpaksa menerimanya sebab tidak mampu berbuat lain. Pendapat dari Stein juga hampir sama dengan Pitlo, menurut Stein dasar

11 Yeni Salma Barlinti, Kedudukan Fatwa Dewan Syariah Nasional dalam Sistem Hukum Nasional di Indonesia (Jakarta: Badan Litbang dan Diklat Kementrian Agama RI, 2010), h. 142.

${ }^{12}$ Sutan Remi Sjahdeini, Kebebasan Berkontrak dan Perlindungan Yang Seimbang Bagi Para Pihak Dalam Perjanjian Kredit di Bank di Indonesia, (Jakarta: Institut Bankir Indonesia, 1993), h. 71. 
132 | de Jure, Jurnal Syariah dan Hukum, Volume 6 Nomor 2, Desember 2014, hlm. 128-137

berlakunya perjanjian baku adalah de fictie van will of vetrouwen sehingga kebebasan berkehendak yang sungguh-sungguh tidak ada pada para pihak, khususnya debitur. ${ }^{13}$

Berdasarkan uraian mengenai perjanjian baku diatas, apabila melihat kembali pada asasasas dari perjanjian menurut Hukum Islam, maka dapat diketahui bahwa tidak adanya kebebasan dalam akad termasuk melanggar asas kebebasan berakad atau dalam istilah bahasa arab disebut dengan mabda' hurriyyah at-ta'aqud. Pada asas kebebasan berakad, para pihak yang melakukan akad harus memiliki dasar suka sama suka atau kerelaan antara masing-masing pihak, tidak boleh ada tekanan, paksaan, penipuan dan mis-statement. Pernyataan ini didasarkan pada firman Allah pada QS. An-Nisa': 29 yang berisi bahwa:

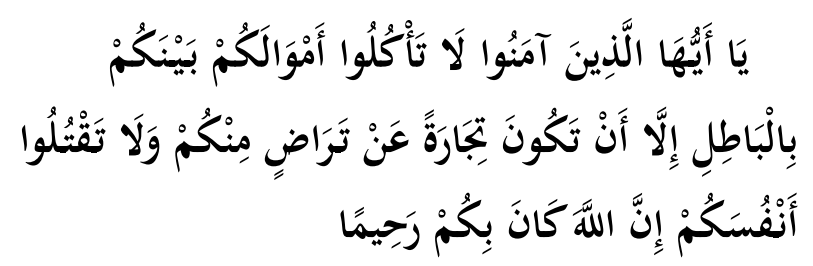

Artinya: "Hai orang-orang yang beriman, janganlah kamu saling memakan harta sesamamu dengan cara yang batil, kecuali dengan jalan perniagaan yang berlaku dengan suka sama suka diantara kamu".

Ayat tersebut secara jelas menjelaskan bahwa dalam hal perdagangan termasuk didalamnya adalah perjanjian harus didasarkan pada suka sama suka atau kerelaan diantara para pihak. Sementara, dalam perjanjian baku cenderung ada unsur keterpaksaan dari pihak debitur untuk menerima setiap klausula perjanjian baku pembiayaan yang mereka ajukan karena posisi debitur pada pihak yang lemah sehingga mau tidak mau debitur akan menerima dan menyetujui setiap syarat yang disebutkan dalam klausul perjanjian. Merujuk pada pada pasal 31 Peraturan Mahkamah Agung Republik Indonesia Nomor 2 Tahun 2008 tentang Kompilasi Hukum Ekonomi

\footnotetext{
13 Alamsyah, Klausula Eksemsi Dalam Kontrak Baku Syariah, (Online), (http://www.papalembang.go.id/index.php?option=com content\& view=article\&id=161:klausula-eksemsi-dalamkontrak-baku-syariah-oleh--alamsyah-303$\underline{\text { \&catid=135: artikel\&Itemid=182. }}$ Diakses tanggal 12 Februari 2015), h. 3.
}

Syariah $^{14}$, paksaan adalah mendorong seseorang melakukan sesuatu yang tidak diridhainya dan tidak merupakan pilihan bebasnya.

Berikut ini merupakan contoh klausul pada perjanjian baku pembiayaan murâbahah:

\section{PEMBATASAN TERHADAP TINDAKAN PIHAK KEDUA}

Selama jangka waktu perjanjian, pihak kedua tidak akan melakukan sebagian atau seluruhnya dari perbuatan-perbuatan sebagai berikut, kecuali setelah mendapatkan persetujuan tertulis dari pihak pertama:

1. Melakukan akuisisi, merger rekonstruksi dan/ atau konsolidasi kegiatan usaha pihak kedua dengan pihak lain.

2. Menjual baik sebagian atau seluruhnya asset pihak kedua yang nyata-nyata mempengaruhi kemampuan atau cara membayar atau melunasi kewajiban pihak keduaatau sisa kewajiban pihak kedua kecuali menjual barang dagangan yang menjadi kegiatan usaha pihak kedua.

3. Membuat utang lain kepada pihak ketiga.

4. Melakukan investasi baru, baik yang berkaitan langsung atau tidak langsung dengan tujuan kegiatan usaha pihak kedua.

5. Memindahkan kedudukan/ lokasi barang maupun barang jaminan dari kedudukan/ lokasi bang barang itu semula atau sepatutnya berada, dan/ atau mengalihkan hak atas barang atau jaminan yang bersangkutan kepada pihak lain.

6. Mengajukan kepada pihak yang berwenang untuk menunjukkan eksekutor, curator, likuidator atau pengawas atas sebagian atau seluruh harta kekayaannya.
${ }^{14}$ Peraturan Mahkamah Agung Republik Indonesia Nomor 2 Tahun 2008 tentang Kompilasi Hukum Ekonomi Syariah adalah suatu pedoman yang diperuntukkan bagi hakim dalam memutus perkara dalam ekonomi syariah. 
Dwi Fidhayanti, Perjanjian Baku Menurut Prinsip Syariah...| 133

\section{RISIKO-RISIKO}

Pihak kedua bertanggung jawab untuk memeriksa dan meneliti kondisi barang yang dibeli dari pemasok, termasuk terhadap sahnya dokumen-dokumen atau surat-surat bukti kepemilikan barang pihak pertama tidak bertanggung jawab atas cacat-cacat tersembunyi atas barang serta tidak bertanggung jawab atas ketidakabsahan dokumen kepemilikan barang. ${ }^{15}$

Klausula-klausula yang telah ditetapkan oleh pihak pertama seperti halnya contoh diatas secara jelas memberikan batasan kepada debitur untuk melakukan tindakan bisnis. Selain itu, pada klausula risiko juga menggambarkan bahwa semua tanggung jawab harus dipikul oleh debitur sebagai pihak kedua. Sementara, pihak bank sebagai pihak pertama tidak bersedia menerima risiko apapun. Klausula-klausula tersebut secara sengaja dicantumkan oleh pihak bank selaku kreditur yang menurut pandangan bank merupakan suatu tindakan proteksi bagi bank apabila debitur melakukan tindakan wanprestasi yang dapat merugikan bank. Nasabah sebagai debitur terkadang tidak memperhatikan isi klausula yang tidak baik atau bahkan merugikan bagi debitur dan hanya memihak pada kepentingan bank. Debitur yang memerlukan dana terpaksa harus menerima setiap klausul perjanjian yang telah dibuat secara baku oleh bank.

Dari segi hukum Islam, perjanjian baku tersebut melihat daripada rukun dalam perjanjian hukum islam, yang berupa pihakpihak yang berakad (al-'aqidain); obyek akad (mahallul 'aqd); tujuan pokok akad (maudhu'ul 'aqd); dan kesepakatan (sîghat al'aqd) telah sah karena rukun-rukun tersebut telah dipenuhi dalam perjanjian. Rukun tersebut telah dipenuhi dalam perjanjian baku pembiayaan pada perbankan syariah dapat diketahui dari perjanjian dimana terdapat dua pihak, yaitu nasabah dan bank, obyeknya dalam pembiayaan jual beli misalnya berupa barang yang diperjual belikan dan harga, tujuannya membiayai sejumlah pembelian, dan kesepakatan kedua belah pihak yang digambarkan dengan ditandatanganinya perjanjian oleh kedua belah pihak.

Selain memperhatikan rukun dalam perjanjian, perjanjian pembiayaan dalam perbankan syariah juga harus memperhatikan pasal Prinsip syariah yang dimaksud kemudian dituangkan pada pasal 1 ayat (12) undangundang No. 21 tahun 2008 tentang perbankan syariah bahwa prinsip syariah adalah prinsip hukum Islam dalam kegiatan perbankan berdasarkan fatwa yang dikeluarkan oleh lembaga yang memiliki kewenangan dalam penetapan fatwa di bidang syariah. Agar fatwa dapat digunakan sebagai dasar hukum yang mengikat, fatwa tersebut harus terlebih dahulu diserap melalui Peraturan Bank Indonesia yang kemudian ditingkatkan menjadi undangundang. Sebagian besar isi pasal sama dengan isi dari fatwa Dewan Syariah Nasional. ${ }^{16}$

Memenuhi prinsip syariah dalam akad atau perjanjian adalah wajib sebagaimana tertuang dalam pasal 2 ayat (2) Peraturan Bank Indonesia Nomor: 10/16/Pbi/2008 Tentang Perubahan Atas Peraturan Bank Indonesia Nomor 9/19/Pbi/2007 Tentang Pelaksanaan Prinsip Syariah Dalam Kegiatan Penghimpunan Dana Dan Penyaluran Dana Serta Pelayanan Jasa Bank Syariah bahwa Dalam melaksanakan jasa perbankan melalui kegiatan penghimpunan dana, penyaluran dana dan pelayanan jasa bank, Bank wajib memenuhi Prinsip Syariah. Lebih lanjut dijelaskan dalam pasal 2 ayat (3) Peraturan Bank Indonesia Nomor: 10/16/Pbi/2008 Tentang Perubahan Atas Peraturan Bank Indonesia Nomor 9/19/Pbi/2007 Tentang Pelaksanaan Prinsip Syariah Dalam Kegiatan Penghimpunan Dana Dan Penyaluran Dana Serta Pelayanan Jasa Bank Syariah bahwa Pemenuhan Prinsip Syariah sebagaimana dimaksud pada ayat (2) dilaksanakan dengan memenuhi ketentuan pokok hukum Islam antara lain prinsip keadilan dan keseimbangan ('adl wa tawâzun), kemaslahatan (maslahah), dan universalisme (alamiyah) serta tidak mengandung gharâr, maysir, riba, zalim dan objek haram.

Ciri perjanjian baku sebagai berikut: (1) Isinya ditetapkan sepihak yang posisinya lebih kuat; (2) Masyarakat dalam hal ini debitor tidak

\footnotetext{
${ }^{15}$ Alamsyah, Klausula.., h. 8-9.
}

${ }^{16}$ Yeni Salma Barlinti, Kedudukan...., h. 447. 
ikut bersama-sama menentukan isi perjanjian;

(3) Terdorong oleh kebutuhan, debitor terpaksa menerima perjanjian itu; (4) Dipersiapkan lebih dahulu secara massal dan kolektif. ${ }^{17}$

Perjanjian baku yang demikian tidak mencerminkan adanya prinsip keseimbangan (tawâzun). Dalam penjelasan pasal pasal 2 ayat (3) Peraturan Bank Indonesia Nomor: 10/16/Pbi/2008 Tentang Perubahan Atas Peraturan Bank Indonesia Nomor 9/19/Pbi/2007 Tentang Pelaksanaan Prinsip Syariah Dalam Kegiatan Penghimpunan Dana Dan Penyaluran Dana Serta Pelayanan Jasa Bank Syariah bahwa Pemenuhan Prinsip Syariah, "Tawâzun" adalah keseimbangan yang meliputi aspek material dan spiritual, aspek privat dan publik, sektor keuangan dan sektor riil, bisnis dan sosial, dan keseimbangan aspek pemanfaatan dan kelestarian. Menurut penulis, dalam hal perjanjian prinsip keseimbangan dalam perjanjian pembiayaan dalam perbakan syariah harus dapat merepresentasikan keseimbangan antara hak dan kewajiban. Hak dan kewajiban menjadi seimbang apabila kedua belah pihak saling berkomunikasi dalam menentukan klausul perjanjian.

Namun, perjanjian baku yang merupakan upaya proteksi bank, menjadikan perjanjian pembiayaan dalam perbankan syariah luput dari adanya adanya keseimbangan antara hak dan kewajiban bagi para pihak. Bank tidak ingin mendapatkan adanya kerugian dalam perjanjian pembiayaan yang dibuatnya dengan nasabah sehingga dengan segala cara bank mencantumkan klausul yang berpihak dan menguntungkan baginya. Nasabah sebagai pihak yang membutuhkan dana, dalam perjanjian baku hanya diberi kesempatan untuk membaca dan menandatangani atau tidak menandatangani perjanjian tersebut. Ini lah yang kemudian membuat perjanjian baku dikenal dengan istilah take it or leave it contract.

Akibat Hukum Dari Perjanjian Baku Pada Pembiayaan Di Perbankan Syariah Bagi Para Pihak

Akibat hukum adalah akibat suatu tindakan yang dilakukan untuk memperoleh suatu akibat yang dikehendaki oleh pelaku dan yang diatur

17 Mariam Darus Badrulzaman, Kompilasi Hukum Perikatan, (Bandung: PT. Citra Aditya Bakti, 2001), h. 69. oleh hukum. Tindakan yang dilakukannya merupakan tindakan hukum yakni tindakan yang dilakukan guna memperoleh sesuatu akibat yang dikehendaki hukum. ${ }^{18}$ Tindakan hukum dalam pembahasan ini, yaitu adanya pembiayaan antara bank dan nasabah yang dituangkan dalam suatu perjanjian. Akibat yang dikehendaki dalam perjanjian pembiayaan bertujuan agar perjanjian tersebut berlaku mengikat bagi para pihak dan terpenuhinya prestasi yang diperjanjikan.

Perjanjian baku yang dapat memenuhi prinsip syariah, maka perjanjian tersebut dapat berlaku mengikat bagi para pihak dan perjanjian tersebut dapat dijadikan bukti untuk para pihak memenuhi prestasi. Artinya perjanjian tersebut sah di mata hukum karena di dalamnya tidak mengandung sesuatu yang dilarang. Sebagaimana kaidah ushul fiqh dalam hukum Islam yang menyatakan bahwa:

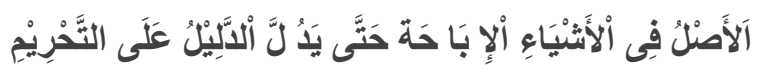

Artinya: "pada asasnya segala sesuatu itu boleh dilakukan sampai ada dalil yang melarangnya".

Bahwa segala sesuatu itu sah dilakukan apabila tidak ada larangan yang secara tegas tidak memperbolehkan tindakan tersebut. Dalam perjanjian baku pada pembiayaan di perbankan syariah, mengharuskan perjanjian dalam hal produk penyaluran dana untuk wajib menerapkan prinsip syariah. Akan tetapi, pada proses pelaksanaannya, perjanjian baku melupakan akan esensi dari prinsip syariah yang berupa keseimbangan (tawâzun). Pada praktiknya, bank tidak memberikan kesempatan bagi nasabah untuk memberikan pendapat dan saran ketika menyusun perjanjian. Bank membuat perjanjian tersebut secara sepihak sehingga besar kemungkinan Bank membuat klausul yang hanya dapat memproteksi dirinya dan menguntungkan bagi pihak bank.

Terdapat tiga kategori akibat hukum dari perjanjian atau akad dari segi hukum Islam, yaitu akad yang sah, akad yang fasad dan akad yang batal. Akad yang dibentuk secara sah berlaku sebagai nash syariah bagi mereka yang mengadakan akad. Sedangkan pada akad fasad

18 Soeroso, R., Pengantar Ilmu Hukum, (Jakarta: Sinar Grafika, 2013), h 295. 
dan akad batal keduanya sama-sama tidak dapat diwujudkan dan tidak memberikan akibat hukum apapun bagi para pihak yang membuat akad.

Perjanjian baku sebagaimana telah diuraikan sebelumnya yang merujuk pada pendapat Pitlo dan Stein, bahwa perjanjian baku temasuk pada perjanjian yang mengandung unsur paksaan. Maksud paksaan dalam pendapat tersebut adalah bahwa nasabah tidak mempunyai kesempatan untuk menolak atau merefisi klausula perjanjian dan sebagai pihak yang membutuhkan dana, nasabah hanya bisa menerima segala klausul dengan cara terpaksa. Namun, sulit sekali untuk membutuhkan hal ini, karena secara hukum perjanjian tersebut dibuat dengan sah dimana dibuktikan dengan adanya tanda tangan dari nasabah dan bank.

Perjanjian baku termasuk pada perjanjian yang sah, akan tetapi perjanjian baku tersebut tidak mengandung salah satu prinsip, yaitu prinsip keseimbangan (tawâzun). Secara hukum Islam, perjanjian tersebut menjadi fasad. Akad yang fasad (dapat dibatalkan), yaitu akad yang terpenuhinya rukun dan syarasyaratnya, tetapi ada segi atau hal lain yang merusak akad tersebut karena pertimbangan maslahat. Oleh karena itu, perjanjian baku tidak dapat berlaku mengikat bagi para pihak.

Undang-undang No. 21 Tahun 2008 tentang Perbankan syariah menentukan dalam pasal 56 bahwa apabila Bank Syariah atau UUS, anggota dewan komisaris, anggota Dewan Pengawas Syariah, direksi, dan/atau pegawai Bank Syariah atau Bank Umum Konvensional yang memiliki UUS, yang menghalangi dan/atau tidak melaksanakan Prinsip Syariah dalam menjalankan usaha atau tugasnya, maka Bank Indonesia menetapkan sanksi administrative. Lebih lanjut mengenai sanksi administratif ditentukan dalam pasal Pasal 58 ayat (1) bahwa Sanksi administratif sebagaimana dimaksud dalam UndangUndang ini adalah: denda uang; teguran tertulis; penurunan tingkat kesehatan Bank Syariah dan UUS; pelarangan untuk turut serta dalam kegiatan kliring; pembekuan kegiatan usaha tertentu, baik untuk kantor cabang tertentu maupun untuk Bank Syariah dan UUS secara keseluruhan; pemberhentian pengurus Bank Syariah dan Bank Umum Konvensional yang memiliki UUS, dan selanjutnya menunjuk dan mengangkat pengganti sementara sampai Rapat Umum Pemegang Saham mengangkat pengganti yang tetap dengan persetujuan Bank Indonesia; pencantuman anggota pengurus, pegawai, dan pemegang saham Bank Syariah dan Bank Umum Konvensional yang memiliki UUS dalam daftar orang tercela di bidang perbankan; dan/atau pencabutan izin usaha.

Secara peraturan memang sudah ditulis sedemikian komplit dan jelas, namun pada pelaksanaanya baik dari pihak bank maupun nasabah masih kurang memahami akan pentingnya membuat perjanjian yang sesuai dengan hukum Islam. Sedangkan dari segi budaya hukum, pegawai bank dan nasabah tidak pernah membaca dengan seksama klausul perjanjian yang berdampak pada sah dan tidaknya perjanjian sehingga dapat berlaku mengikat, dan juga nasabah kurang tanggap akan hal yang seperti ini dengan hanya menganggap perjanjian baku setelah ditanda tangani dianggap sah, namun ketika terjadi wanprestasi atau perbuatan melawan hukum yang dilakukan bank, baru lah dalam gugatannya menyinggung tentang keabsahan dari perjanjian baku itu sendiri.

Suatu peraturan tidak dapat berjalan tanpa berdampingan dengan peraturan lain. Seperti halnya perjanjian yang terdapat pada hukum Islam, menyakut juga aturan-aturan lain yang berkaitan, misalnya peraturan yang terdapat pada pasal 18 undang-undang No. 8 tahun 1998 tentang Perlindungan Konsumen. Pasal 18 undang-undang No. 8 tahun 1998 tentang Perlindungan Konsumen diperlukan agar perjanjian tersebut tetap dalam koridornya sebagai perjanjian baku. Pasal 18 undangundang No. 8 tahun 1998 tentang Perlindungan Konsumen mensyaratkan beberapa larangan untuk perjanjian baku yang isinya adalah sebagai berikut:

Pelaku usaha dalam menawarkan barang dan/atau jasa yang ditujukan untuk diperdagangkan dilarang membuat atau mencantumkan klausula baku pada setiap dokumen dan/atau perjanjian apabila: (a) menyatakan pengalihan tanggung jawab pelaku usaha; (b) menyatakan bahwa pelaku usaha berhak menolak penyerahan kembali barang yang dibeli konsumen; (c) menyatakan bahwa pelaku usaha berhak menolak penyerahan kembali uang yang dibayarkan atas barang 
dan/atau jasa yang dibeli oleh konsumen; (d) menyatakan pemberian kuasa dari konsumen kepada pelaku usaha baik secara langsung maupun tidak langsung untuk melakukan segala tindakan sepihak yang berkaitan dengan barang yang dibeli oleh konsumen secara angsuran; (e) mengatur perihal pembuktian atas hilangnya kegunaan barang atau pemanfaatan jasa yang dibeli oleh konsumen; (f) memberi hak kepada pelaku usaha untuk mengurangi manfaat jasa atau mengurangi harta kekayaan konsumen yang menjadi obyek jual beli jasa; (g) menyatakan tunduknya konsumen kepada peraturan yang berupa aturan baru, tambahan, lanjutan dan/atau pengubahan lanjutan yang dibuat sepihak oleh pelaku usaha dalam masa konsumen memanfaatkan jasa yang dibelinya; (h) menyatakan bahwa konsumen memberi kuasa kepada pelaku usaha untuk pembebanan hak tanggungan, hak gadai, atau hak jaminan terhadap barang yang dibeli oleh konsumen secara angsuran.

Dengan demikian, diharapkan agar perjanjian yang dibuat oleh perbankan syariah memperhatikan dengan cermat atas peraturanperaturan yang terkait dengan perjanjian yang dituangkan dalam setiap produknya, baik dari segi prinsip syariah dan juga peraturan hukum penunjangnya. Tujuannya adalah agar perjanjian tersebut tidak akan menimbulkan hal-hal yang dapat merugikan bagi kedua belah pihak.

\section{DAFTAR PUSTAKA}

Alamsyah, Klausula Eksemsi Dalam Kontrak Baku Syariah, (Online), (http://www.papalembang.go.id/index.php?option=com content\&view=article\&id=161:klausulaeksemsi-dalam-kontrak-baku-syariaholeh--alamsyah-303-

\&catid=135: artikel \&Itemid=182. Diakses tanggal 12 Februari 2015)

Badrulzaman, Mariam Darus, Kompilasi Hukum Perikatan, Bandung: PT. Citra Aditya Bakti, 2001.

Barlinti, Yeni Salma, Kedudukan Fatwa Dewan Syariah Nasional dalam Sistem Hukum Nasional di Indonesia, Jakarta: Badan Litbang dan Diklat Kementrian Agama RI, 2010.

\section{Kesimpulan}

Dari pembahasan mengenai Perjanjian Baku Menurut Prinsip Syariah (Tinjauan Yuridis Terhadap Praktek Pembiayaan di Perbankan Syariah di Indonesia), maka dapat diambil kesimpulannya sebagai berikut: (1) Perjanjian baku telah dibuat secara sah, namun tidak memperhatikan salah satu prinsip syariah yang ditetapkan pada produk penerimaan dan produk penyaluran dana pada perbankan syariah, yaitu keseimbangan (tawâzun). Hak dan kewajiban antara bank dan nasabah tidak seimbang karena klausula perjanjian telah dibuat secara baku oleh bank yang bertujuan untuk memproteksi dirinya dari segala kerugian yang mungkin dilakukan oleh nasabah, sedangkan nasabah tidak diberi kesempatan untuk memberikan pendapat, saran ataupun kesempatan untuk merefisi klausul perjanjian baku pembiayaan tersebut. (2) Perjanjian baku setelah dilakukan analisis menurut prinsip syariah termasuk pada perjanjian yang rusak atau fasid $\mathrm{k}$ arena perjanjian tersebut telah dibuat secara sah, namun terdapat satu prinsip yang tidak dipenuhi yang kemudian membuat perjanjian tersebut tidak dapat diterapkan. perjanjian yang fasid tidak menimbulkan akibat hukum apapun bagi para pihak yang melaksanakan perjanjian sehingga perjanjian tersebut tidak dapat dilaksanakan.

Djumhana, Muhammad, Hukum Perbanakan di Indonesia, Bandung: Citra Aditya Bakti, 1996.

Hermansyah, Hukum Perbankan Nasional Indonesia, Jakarta: Kencana, 2005.

R. Subekti, Hukum Perjanjian, Bandung: Intermasa, 1987.

Sjahdeini, Sutan Remi, Kebebasan Berkontrak dan Perlindungan Yang Seimbang Bagi Para Pihak Dalam Perjanjian Kredit di Bank di Indonesia, Jakarta: Institut Bankir Indonesia, 1993.

Soemitra, Andri, Bank dan Lembaga Keuangan Syariah, cet, ke-2, Jakarta: Kencana, 2010.

Soerjono Soekanto dan Sri Mamudji, Penelitian Hukum Normatif: Suatu 
Tinjauan Singkat, Jakarta: Raja Grafindo Persada, 2011.

Soeroso, R., Pengantar Ilmu Hukum, Jakarta: Sinar Grafika, 2013.

Susamto, Burhanuddin, Aspek Hukum Lembaga Keuangan Syariah. Yogyakarta: Graha Ilmu, 2010.

Susanti, Dhyah Ochtorina. Mekanisme Pengaturan Hukum Perjanjian Dalam Regulasi perbankan Syariah di Indonesia (Ditunjau dari Sudut Pandang Hukum Islam dan Hukum Perdata (KUHPerdata yang berlaku di Indonesia), Risalah Hukum (Online) Volume 4 No. 2 (http://risalah.fhunmul.ac.id diakses tanggal 12 Februari 2015)

Wignyosubroto, Soetandyo, Hukum, Paradigma, Metode dan Dinamika Masalahnya. Jakarta: ELSAM dan HUMA, 2002. 